\title{
An Acetylacetonate or a Pyrazole? Both! 3-(3,5-Dimethyl-pyrazol-4- yl)pentane-2,4-dione as a Ditopic Ligand
}

\author{
Qianqian Guo and Ulli Englert* \\ Institute of Inorganic Chemistry, RWTH Aachen University, 52074 Aachen, Germany
}

Supporting Information

ABSTRACT: The alternative coordination sites of 3-(3,5-dimethylpyrazol-4-yl)pentane-2,4-dione $\left(\mathrm{H}_{2} \mathrm{acacPz}\right)$ differ with respect to Pearson hardness. The softer, heterocyclic moiety was used as $\mathrm{N}$ donor toward $\mathrm{Zn}(\mathrm{II})$ and $\mathrm{Ag}(\mathrm{I})$; it yielded a tetrahedral, neutral $\mathrm{Zn}$ complex in the former and a monocationic, linear bis(ligand) Ag complex in the latter case. After deprotonation with silver benzoate, the pyrazolyl ring may act as a monoanionic $N, N^{\prime}$-bridge between neighboring cations in a hexanuclear Ag aggregate; in addition to ligand-supported $\mathrm{Ag} \cdots \mathrm{Ag}$ distances of ca. $3.2 \AA$, these aggregates feature ligand-unsupported argentophilic interactions of ca. 2.9 $\AA$. With stronger bases and in the presence of oxophilic $\mathrm{Mg}$ cations, the harder hydroxyketone part of the $\mathrm{H}_{2}$ acacPz ligand may be deprotonated to a chelating acetylacetonate. The

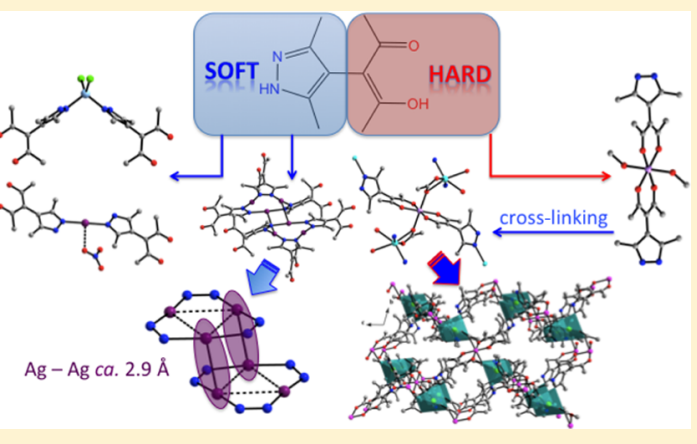
resulting bis(ligand) $\mathrm{Mg}$ complex has been used as starting compound for a bimetallic derivative: the ditopic ligand allows coordinating cadmium acetate to its dangling $\mathrm{N}$ donor site, thus, bridging divalent $\mathrm{Mg}$ and $\mathrm{Cd}$ in a bimetallic three-dimensional coordination network of pts topology.

\section{INTRODUCTION}

Ligands with two or more coordination sites allow for assembling cations to coordination polymers. The wide range of cations and the plethora of potential linkers have given rise to considerable scientific efforts and to almost countless publications documenting syntheses, structures, and applications of such compounds. Ditopic ligands with two distinctly different coordination sites allow combining different metal centers and thus add an additional degree of freedom to these complex solids. Substituted acetylacetonates have often been used in this context; we here focus on derivatives with a potential $\mathrm{N}$ donor substituent in the 3 position. Scheme 1 compiles three of these ditopic acetylacetones: for $\mathrm{HacacCN}$, an efficient synthesis was introduced by Silvernail et al. ${ }^{1}$ This ligand acts as a (substituted) acetylacetonate toward many different cations, but successive $\mathrm{N}$ coordination is limited to $\mathrm{Ag}$ or $\mathrm{Cu}^{2-8} \mathrm{~A}$ different coordination behavior was observed for the pyridyl derivative HacacPy. It was first applied as linker in a discrete supramolecular structure. ${ }^{9}$ Complexes in which this ligand acts as $\mathrm{O}^{10}$ or $\mathrm{N}^{11}$ donor and extended bimetallic structures in which it links different cations ${ }^{10-15}$ have been described. Quite obviously, HacacPy is a significantly better $\mathrm{N}$ donor than HacacCN. In addition to cation coordination, the pyridyl $\mathrm{N}$ has been used as nucleophilic group in halogen bonds. ${ }^{16}$ We now wish to report our results concerning the pyrazolyl-substituted ditopic ligand 3-(3,5-dimethyl-pyrazol-4yl)pentane-2,4-dione, $\mathrm{H}_{2}$ acacPz. A beryllium complex of this compound was published by Boldog et al. ${ }^{17}$ Similar to the aforementioned alternatives, $\mathrm{H}_{2}$ acacPz offers $\mathrm{O}$ and $\mathrm{N}$ donor sites of different Pearson hardness; ${ }^{18}$ in addition, both the pyrazolyl and the acetylacetone moiety may be deprotonated, and the question about preferred $O$ or $N$ coordination has not yet been answered. Moving from single site coordination to ditopic topology, $\mathrm{H}_{2}$ acacPz should rank in-between the shorter acacCN $^{-}$and the longer acacPy linker: The former is associated with metal $\cdots$ metal distances of ca. $8 \AA$, the latter of ca. $9.7 \AA$, whereas, for the yet unexplored HacacPz $\mathrm{H}^{-}$bridge, ca. $9 \AA$, which were expected based on simple geometry considerations. We here communicate the synthesis and characterization of $N$ coordinated, $N, N^{\prime}$ bridging, $O$ coordinated, and $O, N^{\prime}$ bimetallic complexes. Scheme 2 compiles the compounds synthesized and structurally characterized in the context of this work.

\section{RESULTS AND DISCUSSION}

We start our survey of the coordination modes of $\mathrm{H}_{2} \mathrm{acacPz}$ by using the ligand as an $\mathrm{N}$ donor without deprotonation. With $\mathrm{ZnCl}_{2}$, the neutral mononuclear complex $\left[\mathrm{ZnCl}_{2}\left(\mathrm{H}_{2} \mathrm{acacPz}\right)_{2}\right]$, $\mathbf{1}$, is obtained. The metal cation is located on a 2 -fold crystallographic axis and adopts an almost undistorted tetrahedral coordination. This reaction product is depicted in Figure 1. The $\mathrm{N}$ coordinated $\mathrm{H}_{2}$ acacPz molecules subtend an interligand angle of $106.4^{\circ}$ and unambiguously correspond to the enol tautomer, with significantly different $\mathrm{C}-\mathrm{C}$ and $\mathrm{C}-\mathrm{O}$ bond distances in the acetylacetone moiety as shown in Scheme 3.

Received: May 9, 2016

Revised: July 15, 2016

Published: August 2, 2016 


\section{Scheme 1. Three N Donor Substituted Acetylacetonates with Different M⿻.M Distances}

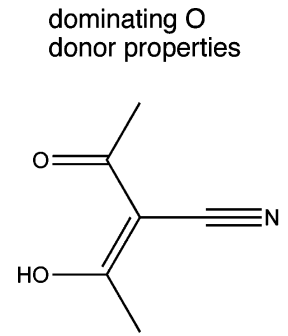

HacacCN

$M \cdots M 8.0(3) \AA$

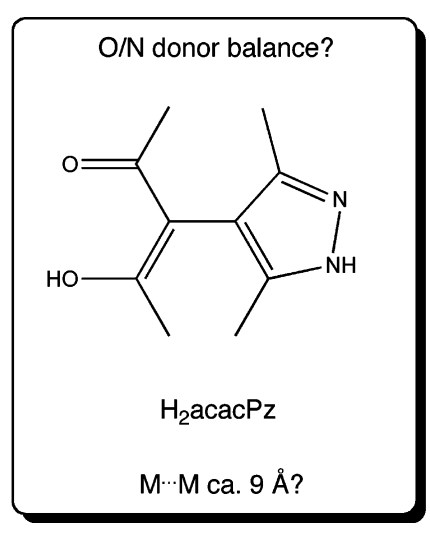

dominating $\mathrm{N}$

donor properties

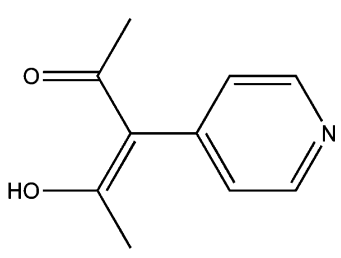

HacacPy

$M \cdots M 9.7(3) \AA$

Scheme 2. Synthesis and Composition of the Coordination Compounds 1-4 and the Bimetallic Polymeric Solid 5

Nitrogen coordination<smiles></smiles><smiles></smiles>

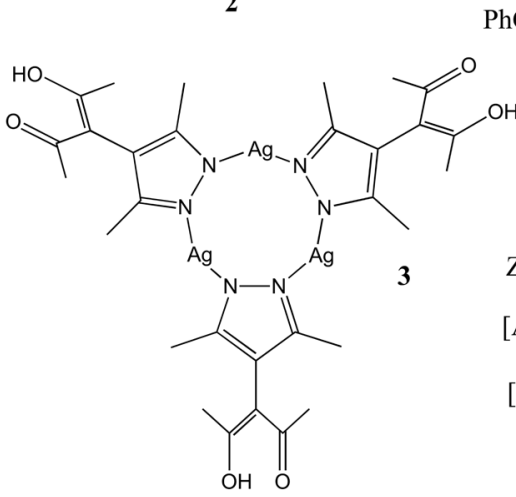
$\mathrm{PhC}$<smiles>CCCCCOC(C)(C)C</smiles>

4

Oxygen coordination

$\mathrm{ZnCl}_{2}\left(\mathrm{H}_{2} \mathrm{acacPz}\right)_{2}$

$\left[\mathrm{Ag}\left(\mathrm{H}_{2} \mathrm{acacPz}\right)_{2}\right] \mathrm{NO}_{3} \cdot \mathrm{H}_{2} \mathrm{O}$

2

$\left.\mathrm{Ag}_{6}(\mathrm{HacacPz})_{6}\right]$ solvates

3

This enol geometry derived from the diffraction experiment matches the IR spectrum of $\mathbf{1}$, and we anticipate that the same pattern is encountered in the spectra of 2,3 and that of the uncoordinated ligand $\mathrm{H}_{2}$ acacPz itself: No IR absorptions in the region of $1720 \mathrm{~cm}^{-1}$ were observed; they would be expected for a diketone, e.g., for unsubstituted acetylacetone. ${ }^{19} \mathbf{1}$ shows a Raman band at $290 \mathrm{~cm}^{-1}$; a resonance in the same range had been assigned to the $\mathrm{Zn}-\mathrm{N}$ vibration in the tetrahedral complex $\left.\left[\mathrm{ZnCl}_{2} \text { (pyridine) }\right)_{2}\right]{ }^{19}$ Intermolecular $\mathrm{N}-\mathrm{H} \cdots \mathrm{Cl}$ contacts in $\mathbf{1}$ are rather long and bifurcated (Figure 1).

Reaction of $\mathrm{AgNO}_{3}$ with the neutral ligand $\mathrm{H}_{2}$ acacPz leads to a cationic $\left[\mathrm{Ag}\left(\mathrm{H}_{2} \mathrm{acacPz}\right)_{2}\right]^{+}$complex with nitrate as counteranion. This salt 2 crystallizes as a monohydrate in space group $P \overline{1}$. Cations and anions occupy alternating crystallographic centers of inversion along the $b$ axis with shortest Ag $\cdots \mathrm{O}$ (nitrate) distances of $2.894 \AA$ (Figure 2). The $\overline{1}$ site symmetry imposes linear coordination for the metal center in the $\left[\mathrm{Ag}\left(\mathrm{H}_{2} \mathrm{acacPz}\right)_{2}\right]^{+}$moiety and implies orientational disorder (see the Experimental Section) for the nitrate anion and a closely associated water molecule. In $\mathbf{2}$, hydrogen bonds link the ionic residues and the cocrystallized water molecule; details have been compiled in the Supporting Information. The Ag-N vibration in the cation is associated with a band at $240 \mathrm{~cm}^{-1}$ in the Raman spectrum. ${ }^{20}$

In contrast to the alternative ditopic ligands shown in Scheme $1, \mathrm{H}_{2}$ acacPz may be deprotonated at either the $\mathrm{N}$ or the $\mathrm{O}$ donor site. In the presence of (soft) silver cations, benzoate is sufficiently basic to deprotonate the pyrazolyl moiety and the deprotonated anionic ligand $\mathrm{HacacPz}^{-} \mathrm{N}, N^{\prime}$ bridges two $\operatorname{Ag}(\mathrm{I})$ cations; this coordination mode is observed in the closely related compounds $\mathbf{3 a}, \mathbf{3 b}$, and $\mathbf{3 c}$. All three solids feature similar discrete $\left[\mathrm{Ag}_{6}(\mathrm{HacacPz})_{6}\right]$ molecules with 


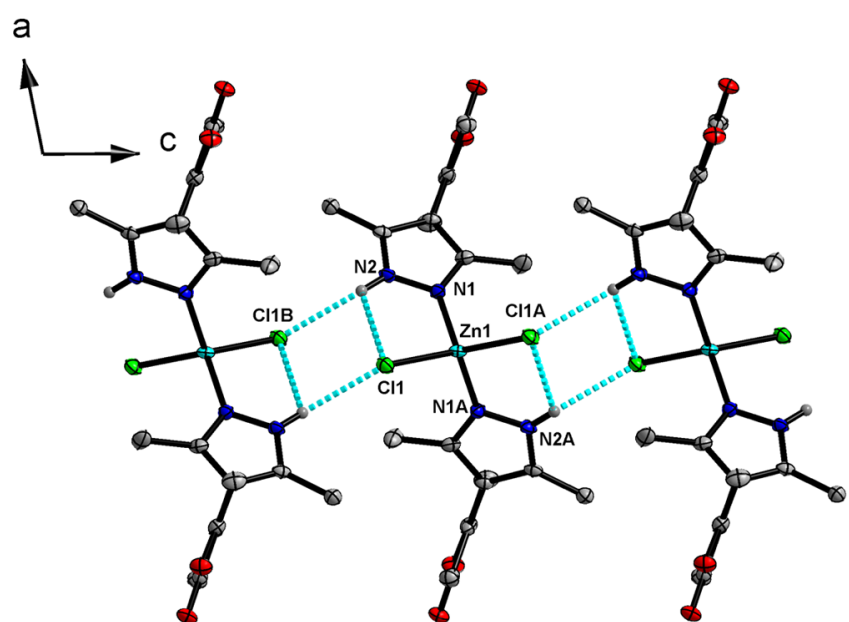

Figure 1. Coordination environment of $\mathrm{Zn}$ (II) and the bifurcate N$\mathrm{H} \cdots \mathrm{Cl}$ contacts in $\mathbf{1}$. Ellipsoids are drawn at $50 \%$ probability; only the $\mathrm{H}$ atoms at $\mathrm{N} 2$ are shown. $d_{\mathrm{N} 2-\mathrm{H}}=0.881 \AA \AA_{;} d_{\mathrm{H} \cdots \mathrm{Cl} 1}=2.792 \AA$; $d_{\mathrm{N} 2-H \cdots C l 1}=3.363 \AA ; d_{H \cdots C l 1 B}=2.536 \AA ; d_{N 2-H \cdots C l B}=3.244 \AA ;$ $\angle_{N 2-H \cdots C l 1}=123.87^{\circ} ; \angle_{N 2-H \cdots C l 1 B}=137.86^{\circ}$. Symmetry operations: $A$ $=1-x, y, 1.5-z ; \mathrm{B}=1-x, 2-y, 1-z$.

Scheme 3. Enol Geometry for $\mathrm{H}_{2}$ acacPz Observed in the Diffraction Experiment on $1^{a}$

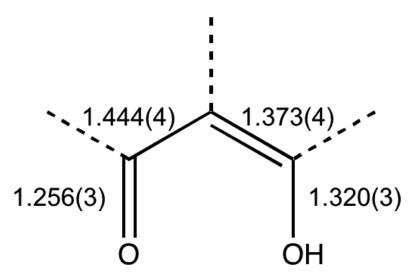

${ }^{a} \mathrm{~A}$ very similar pattern of comparable accuracy was encountered in crystals of 2 .

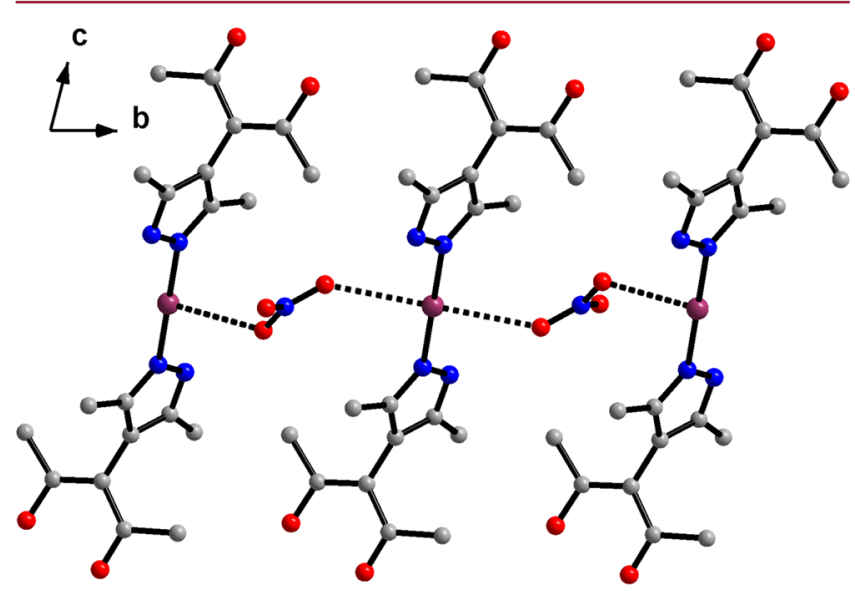

Figure 2. Arrangement of $\left[\mathrm{Ag}\left(\mathrm{H}_{2} \mathrm{acacPz}\right)_{2}\right]^{+}$cations and nitrate anions along the $b$ axis. Dashed lines indicate Ag... O contacts of ca. $2.8 \AA$; hydrogen atoms and orientational disorder in the nitrate have been omitted.

crystallographic $\overline{1}$ symmetry: 3 a contains one and the isomorphous compounds $\mathbf{3 b}$ and $3 \mathbf{c}$ two such independent residues. Therefore, five symmetrically independent hexanuclear $\left[\mathrm{Ag}_{6}(\mathrm{HacacPz})_{6}\right]$ aggregates have been characterized in total and are compared in the Supporting Information. In Figure 3, we restrict our comparison to the $\mathrm{Ag}_{6} \mathrm{~N}_{12}$ cores in $3 \mathrm{a}$ and $\mathbf{3 b}$. In all independent $\left[\mathrm{Ag}_{6}(\mathrm{HacacPz})_{6}\right]$ molecules, pairs of
$\mathrm{Ag}_{3}$ triangles form; their $\mathrm{Ag} \cdots \mathrm{Ag}$ edges (dashed lines) range between 3.3 and $3.5 \AA$ and are bridged by monoanionic $\mathrm{HacacPz} z^{-}$ligands.

Aggregation of these triangles to a hexanuclear moiety is achieved via significantly shorter $\mathrm{Ag}-\mathrm{Ag}$ contacts of ca. $2.9 \AA$. In view of the fact that these interactions occur directly and without any bridging ligand, even the term "cluster" might apply. Due to the concomitant presence of ligand supported and ligand unsupported contacts, we prefer the more general expression "aggregate". Table 1 compiles the Ag...Ag distances in the five symmetrically independent aggregates in $\mathbf{3 a}, \mathbf{3 b}$, and 3c. Short Ag...Ag contacts are generally referred to as "argentophilic", $21-29$ and this type of interactions has recently been reviewed. ${ }^{30}$ More specifically, pyrazolyl-bridged $\mathrm{Ag}$ triangles represent a rather well-established oligonuclear aggregate: In the CSD database, ${ }^{31,32}$ coordinates for 43 wellordered and error-free occurences of this fragment are available, with an average length for the pyrazolyl-bridged edges of 3.469 $\AA$. The second feature encountered in the case of our hexanuclear aggregates, namely, short ligand-unsupported argentophilic interactions to neighboring triangles, is less popular. Fujisawa and co-workers ${ }^{33}$ have contributed five analogous structures and also compiled related examples from the literature. To the best of our knowledge, 3a exhibits the shortest $\mathrm{Ag}-\mathrm{Ag}$ distances between neighboring $\left[\mathrm{Ag}_{3^{-}}\right.$ (pyrazolyl) ${ }_{3}$ ] moieties; slightly longer contacts between 2.9 and $3.0 \AA$ have been reported in a few cases. ${ }^{34-36}$

In the solids $\mathbf{3 a}, \mathbf{3 b}$, and $\mathbf{3 c}$, solvent molecules fill the voids between the large $\left[\mathrm{Ag}_{6}(\mathrm{HacacPz})_{6}\right]$ aggregates (see Tables 2 and 3). 3a contains two molecules of ethanol per unit cell or hexanuclear aggregate. In $3 \mathbf{b}$, eight molecules of ethanol per unit cell occupy two voids. A more complex situation was encountered in the case of $3 \mathrm{c}$ : The compound contains a welllocalized $\mathrm{CH}_{2} \mathrm{Cl}_{2}$ with half-occupied atom sites in a general position, i.e., one $\mathrm{CH}_{2} \mathrm{Cl}_{2}$ per unit cell and three strongly disordered molecules of 2-butanol in two voids per unit cell (see the Experimental Section).

A decision concerning keto-enol tautomerism in 3 is less obvious because the structure models for these solids have to account for larger asymmetric units, comprise chlathrated solvent molecules, and hence are associated with higher standard uncertainties. The IR spectra of 3, however, closely match those of $\mathbf{1}$ and $\mathbf{2}$ for which the diffraction results are unambiguous. A synopsis of the IR spectra of $\mathrm{H}_{2} \mathrm{acacPz}, 1,2$, and 3 is provided in the Supporting Information. $\mathrm{The} \mathrm{Ag}-\mathrm{Ag}$ vibrations in 3 are difficult to assign; they will necessarily be observed at low wavenumbers in the Raman spectra and probably not correspond to pure $\mathrm{Ag}-\mathrm{Ag}$ stretching. A resonance at $83 \mathrm{~cm}^{-1}$ has been associated with a metal $\cdots$ metal contact slightly shorter than $3 \AA \AA^{37}$ Our experimental Raman spectrum of $\mathbf{3}$ (Figure S12) shows a broad band with a shoulder between 100 and $50 \mathrm{~cm}^{-1}$, but we do not have sufficient information from Raman spectra of related compounds to suggest a reliable assignment.

In all compounds discussed so far, the acetylacetone part is protonated but the hydroxyl group is not involved in any short intermolecular interactions. Rather, intramolecular $\mathrm{O}-\mathrm{H} \cdots \mathrm{O}$ hydrogen bonds with donor $\cdots$ acceptor distances between 2.4 and $2.5 \AA$ occur within each Hacac moiety.

In the absence of soft coordination partners, more drastic conditions are required for deprotonation in the $\mathrm{O}$ donor part of the ditopic ligand. Magnesium methoxide proved a suitable reagent, combining the oxophilic nature of the cation with the 

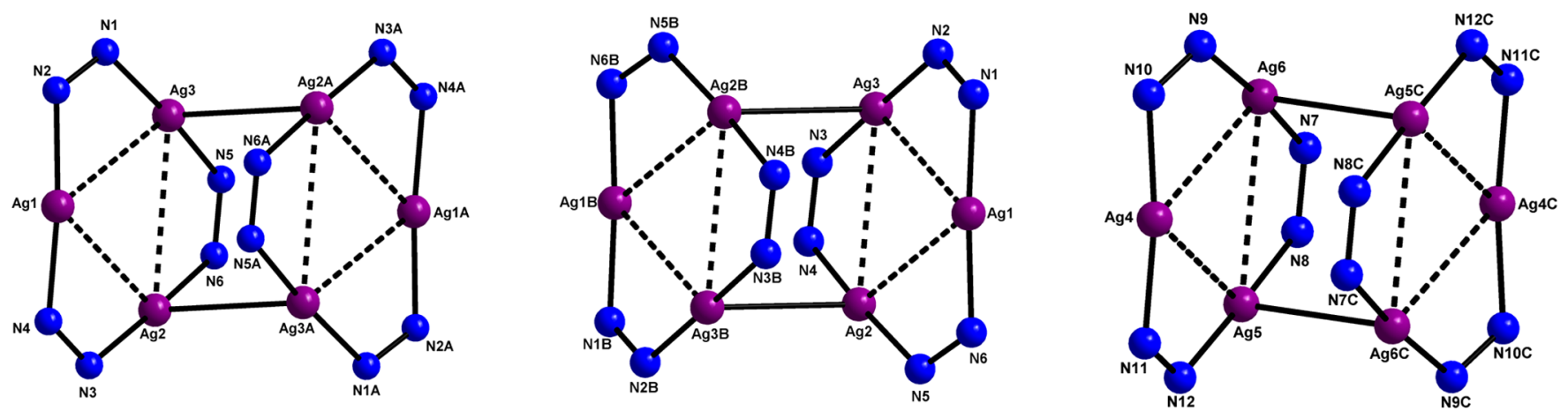

Figure 3. $\mathrm{Ag}_{6}(\mathrm{HacacPz})_{6}$ cores in compounds $\mathbf{3 a}$ (left) and $\mathbf{3 b}$ (middle and right). Symmetry operations: $\mathrm{A}=1-x, 1-y, 1-z ; \mathrm{B}=1-x, 2-y$, $-z$; $\mathrm{C}=1-x, 1-y, 1-z$.

Table 1. Ag.*Ag Distances in $\mathrm{Ag}_{6}(\mathrm{HacacPz})_{6}$ Aggregates in Compounds $3 a, 3 b$, and $3 c$

\begin{tabular}{lcc} 
compound & ligand support interaction range $(\AA)$ & direct interaction $(\AA)$ \\
\hline 3a & $3.329-3.477$ & 2.905 \\
3b resd. 1 & $3.419-3.436$ & 2.969 \\
3b resd. 2 & $3.376-3.474$ & 2.911 \\
3c resd. 1 & $3.420-3.432$ & 3.006 \\
3c resd. 2 & $3.370-3.499$ & 2.906 \\
\hline
\end{tabular}

required basicity of the anion. Crystals of the target product 4 could be directly isolated from the reaction mixture. The diffraction experiment revealed that 4 crystallizes in the orthorhombic space group $\mathrm{Pbca}$ with the central $\mathrm{Mg}$ cation located on a crystallographic center of inversion. It is coordinated by six oxygen atoms in a slightly distorted octahedral geometry. Four oxygen atoms from two $O, O^{\prime}$ chelating $\mathrm{HacacPz}$ ligands are coplanar, and two coordinated apical $\mathrm{MeOH}$ molecules complete the coordination sphere with slightly longer $\mathrm{Mg}-\mathrm{O}$ bonds (Figure 4, left). In addition, 4 contains two molecules of uncoordinated $\mathrm{MeOH}$ per $\mathrm{Mg}$ complex. The NH group of the pyrazolyl ring and the hydroxyl groups of the coordinated and the uncoordinated methanol molecules act as donors, the unprotonated pyrazolyl $\mathrm{N}$, one of the $\mathrm{Mg}$-coordinated $\mathrm{HacacPz}$ oxygen atoms, and the oxygen of the uncoordinated $\mathrm{MeOH}$ as acceptors for classical hydrogen bonds; they subtend a three-dimensional network (Figure 4, right, and Table S2 in the Supporting Information).

A comparison of $\mathbf{4}$ with the only prior structural result obtained for the ligand $\mathrm{HacacPz}$, its complex with the lighter congener $\mathrm{Be},{ }^{17}$ reveals clear differences. The alkaline earth cation in the latter is only four-coordinated, in agreement with general trends: a search in the $\mathrm{CSD}^{32}$ resulted in 109 structures with $\mathrm{BeO}_{4}$ fragments, whereas only one example of hexacoordinated $\mathrm{Be}$ with dubious charge balance has been reported. In contrast, 6-fold coordination for $\mathrm{Mg}$ cations is unexceptional. The oxygen atoms in the $\mathrm{BeO}_{4}$ core investigated by Boldog et al. ${ }^{17}$ subtend an almost undistorted tetrahedron,

Table 2. Crystal Data and Refinement Results for $N$ Coordination Compounds 1, 2, 3a, and $3 b$

\begin{tabular}{|c|c|c|c|c|}
\hline & 1 & 2 & $3 a$ & $3 b$ \\
\hline empirical formula & $\mathrm{C}_{20} \mathrm{H}_{28} \mathrm{Cl}_{2} \mathrm{~N}_{4} \mathrm{O}_{4} \mathrm{Zn}$ & $\mathrm{C}_{20} \mathrm{H}_{30} \mathrm{AgN}_{5} \mathrm{O}_{8}$ & $\mathrm{C}_{64} \mathrm{H}_{90} \mathrm{Ag}_{6} \mathrm{~N}_{12} \mathrm{O}_{14}$ & $\mathrm{C}_{68} \mathrm{H}_{102} \mathrm{Ag}_{6} \mathrm{~N}_{12} \mathrm{O}_{16}$ \\
\hline moiety formula & $\mathrm{C}_{20} \mathrm{H}_{28} \mathrm{Cl}_{2} \mathrm{~N}_{4} \mathrm{O}_{4} \mathrm{Zn}$ & $\mathrm{C}_{20} \mathrm{H}_{28} \mathrm{AgN}_{4} \mathrm{O}_{4}, \mathrm{NO}_{3}, \mathrm{H}_{2} \mathrm{O}$ & $\mathrm{C}_{60} \mathrm{H}_{78} \mathrm{Ag}_{6} \mathrm{~N}_{12} \mathrm{O}_{12}, 2\left(\mathrm{C}_{2} \mathrm{H}_{6} \mathrm{O}\right)$ & $\mathrm{C}_{60} \mathrm{H}_{78} \mathrm{Ag}_{6} \mathrm{~N}_{12} \mathrm{O}_{12}, 4\left(\mathrm{C}_{2} \mathrm{H}_{6} \mathrm{O}\right)$ \\
\hline formula weight ( $\mathrm{g} / \mathrm{mol})$ & 524.73 & 576.36 & 1898.69 & 1990.84 \\
\hline crystal description & colorless plate & colorless block & colorless rod & colorless block \\
\hline crystal size $(\mathrm{mm})$ & $0.29 \times 0.17 \times 0.09$ & $0.19 \times 0.18 \times 0.10$ & $0.16 \times 0.09 \times 0.08$ & $0.27 \times 0.27 \times 0.16$ \\
\hline crystal system & monoclinic & triclinic & triclinic & triclinic \\
\hline space group & $\mathrm{C} 2 / \mathrm{c}$ & $P \overline{1}$ & $P \overline{1}$ & $P \overline{1}$ \\
\hline$a(\AA)$ & $25.914(3)$ & $6.311(4)$ & $11.250(2)$ & $10.780(4)$ \\
\hline$b(\AA)$ & $7.3777(9)$ & $7.438(5)$ & $14.032(3)$ & $14.439(6)$ \\
\hline$c(\AA)$ & $12.9236(16)$ & $13.725(9)$ & $14.434(3)$ & $26.241(10)$ \\
\hline$\alpha(\operatorname{deg})$ & & $74.584(12)$ & $117.441(3)$ & $74.511(6)$ \\
\hline$\beta(\operatorname{deg})$ & $101.076(2)$ & $82.418(12)$ & $110.836(3)$ & $86.050(7)$ \\
\hline$\gamma(\mathrm{deg})$ & & $71.287(11)$ & $90.525(4)$ & $87.599(7)$ \\
\hline$V\left(\AA^{3}\right)$ & $2424.8(5)$ & $587.4(7)$ & $1848.3(6)$ & $3925(3)$ \\
\hline$Z$ & 4 & 1 & 1 & 2 \\
\hline$\mu\left(\mathrm{mm}^{-1}\right)$ & 1.266 & 0.914 & 1.625 & 1.537 \\
\hline total/unique reflections & $6570 / 2215$ & $5371 / 2399$ & $16103 / 7252$ & $35904 / 16091$ \\
\hline$R_{\text {int }}$ & 0.0602 & 0.0530 & 0.0640 & 0.0869 \\
\hline$R\left[F^{2}>2 \sigma\left(F^{2}\right)\right]$ & 0.0307 & 0.0450 & 0.0570 & 0.0531 \\
\hline$w R_{2}\left(F^{2}\right)$ & 0.0983 & 0.0975 & 0.1385 & 0.0972 \\
\hline GOF & 1.050 & 1.019 & 1.008 & 0.985 \\
\hline no. of parameters & 151 & 172 & 454 & 835 \\
\hline$\Delta_{\rho \max } / \Delta_{\rho \min }\left(e \AA^{-3}\right)$ & $0.442 /-0.579$ & $0.935 /-1.237$ & $1.395 /-1.227$ & $1.521 /-1.379$ \\
\hline CCDC & 1478683 & 1478684 & 1478685 & 1478686 \\
\hline
\end{tabular}


Table 3. Crystal Data and Refinement Results for $O$ Coordination Compound 4 and Bimetallic Compounds 5a and $5 b$

\begin{tabular}{|c|c|c|c|c|}
\hline & $3 c$ & 4 & $5 a$ & $5 \mathbf{b}$ \\
\hline empirical formula & $\mathrm{C}_{66.5} \mathrm{H}_{94} \mathrm{Ag}_{6} \mathrm{ClN}_{12} \mathrm{O}_{13.5}$ & $\mathrm{C}_{24} \mathrm{H}_{42} \mathrm{MgN}_{4} \mathrm{O}_{8}$ & $\mathrm{C}_{24} \mathrm{H}_{32} \mathrm{Cd}_{1.06} \mathrm{Mg}_{0.94} \mathrm{~N}_{4} \mathrm{O}_{8}$ & $\mathrm{C}_{24} \mathrm{H}_{32} \mathrm{Cd}_{1.14} \mathrm{Mg}_{0.86} \mathrm{~N}_{4} \mathrm{O}_{8}$ \\
\hline moiety formula & $\mathrm{C}_{60} \mathrm{H}_{78} \mathrm{Ag}_{6} \mathrm{~N}_{12} \mathrm{O}_{12}, 0.5\left(\mathrm{CH}_{2} \mathrm{Cl}_{2}\right), 1.5\left(\mathrm{C}_{4} \mathrm{H}_{10} \mathrm{O}\right)$ & $\mathrm{C}_{22} \mathrm{H}_{34} \mathrm{MgN}_{4} \mathrm{O}_{6}, 2\left(\mathrm{CH}_{4} \mathrm{O}\right)$ & $\mathrm{C}_{24} \mathrm{H}_{32} \mathrm{Cd}_{1.06} \mathrm{Mg}_{0.94} \mathrm{~N}_{4} \mathrm{O}_{8}$ & $\mathrm{C}_{24} \mathrm{H}_{32} \mathrm{Cd}_{1.14} \mathrm{Mg}_{0.86} \mathrm{~N}_{4} \mathrm{O}_{8}$ \\
\hline formula weight $(\mathrm{g} / \mathrm{mol})$ & 1960.21 & 538.92 & 646.52 & 653.36 \\
\hline crystal description & colorless block & colorless block & colorless block & colorless block \\
\hline crystal size $(\mathrm{mm})$ & $0.23 \times 0.23 \times 0.17$ & $0.27 \times 0.25 \times 0.20$ & $0.16 \times 0.14 \times 0.13$ & $0.23 \times 0.18 \times 0.17$ \\
\hline crystal system & triclinic & orthorhombic & monoclinic & monoclinic \\
\hline space group & $P \overline{1}$ & $P b c a$ & $\mathrm{C} 2 / \mathrm{c}$ & $\mathrm{C} 2 / \mathrm{c}$ \\
\hline$a(\AA)$ & $10.8760(11)$ & $14.085(5)$ & $13.494(5)$ & $13.490(3)$ \\
\hline$b(\AA)$ & $14.5740(14)$ & $13.903(5)$ & $15.208(6)$ & $15.129(4)$ \\
\hline$c(\AA)$ & $26.271(3)$ & $15.487(5)$ & $15.540(6)$ & $15.529(4)$ \\
\hline$\alpha(\mathrm{deg})$ & $74.177(2)$ & & & \\
\hline$\beta(\mathrm{deg})$ & $86.005(2)$ & & $110.905(7)$ & $110.683(4)$ \\
\hline$\gamma(\operatorname{deg})$ & $88.246(2)$ & & & \\
\hline$V\left(\AA^{3}\right)$ & $3966.2(7)$ & $3032.9(19)$ & 2979.3(19) & $2965.0(13)$ \\
\hline$z$ & 2 & 4 & 4 & 4 \\
\hline$\mu\left(\mathrm{mm}^{-1}\right)$ & 1.538 & 0.106 & 0.843 & 0.900 \\
\hline total/unique reflections & $43747 / 14425$ & $8607 / 3031$ & $12442 / 2777$ & $8489 / 3066$ \\
\hline$R_{\text {int }}$ & 0.0557 & 0.0770 & 0.1516 & 0.0939 \\
\hline$R\left[F^{2}>2 \sigma\left(F^{2}\right)\right]$ & 0.0539 & 0.0532 & 0.0593 & 0.0714 \\
\hline$w R_{2}\left(F^{2}\right)$ & 0.1679 & 0.1166 & 0.1376 & 0.1892 \\
\hline GOF & 1.033 & 1.016 & 0.968 & 1.081 \\
\hline no. of parameters & 862 & 184 & 183 & 184 \\
\hline$\Delta_{\rho \max } / \Delta_{\rho \min }\left(e \AA^{-3}\right)$ & $1.601 /-0.819$ & $0.274 /-0.286$ & $0.935 /-1.237$ & $2.403^{a} /-1.564^{b}$ \\
\hline $\mathrm{CCDC}$ & 1478687 & 1478688 & 1478689 & 1478690 \\
\hline
\end{tabular}
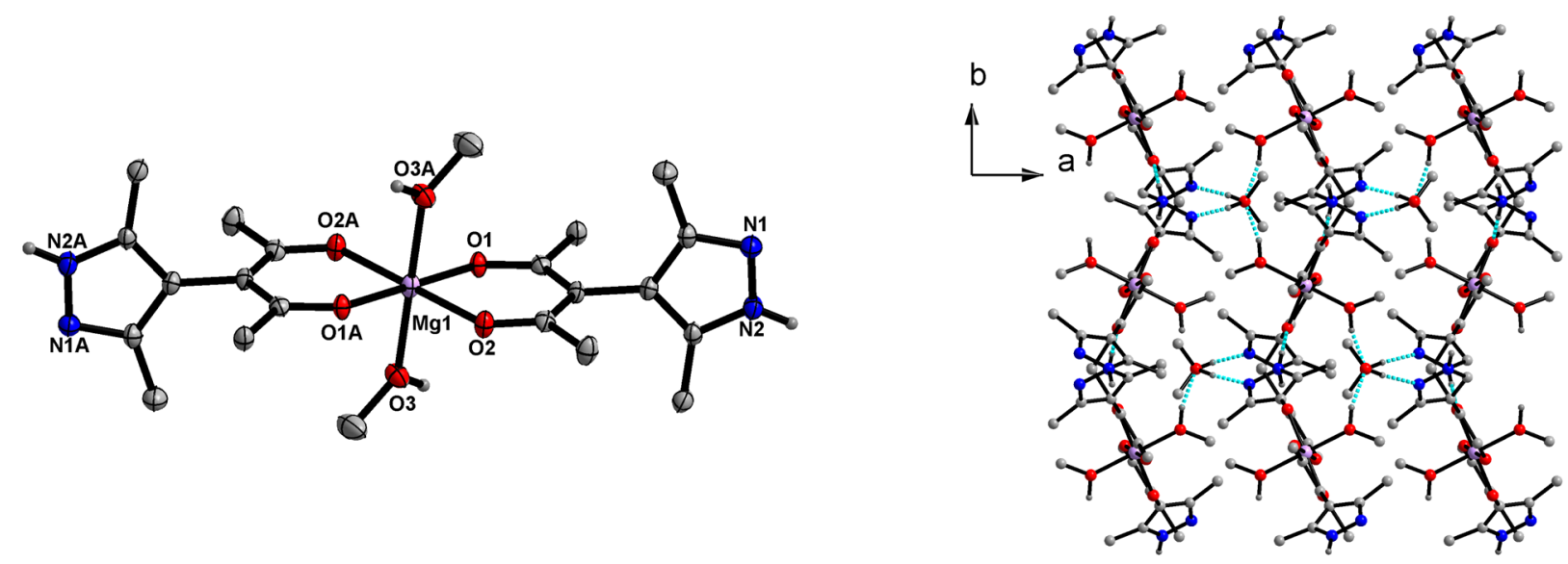

Figure 4. Left: $\mathrm{Mg}(\mathrm{II})$ complex in the crystal structure of 4. Ellipsoids are drawn at 50\% probability, only the $\mathrm{H}$ atoms at $\mathrm{N} 2$ and $\mathrm{O} 3$ are shown. Symmetry operation: $\mathrm{A}=1-x, 1-y, 1-z$. Right: $\mathrm{N}-\mathrm{H} \cdots \mathrm{O}$ and $\mathrm{O}-\mathrm{H} \cdots \mathrm{O}$ interactions (dashed blue lines) in the crystal structure of 4.
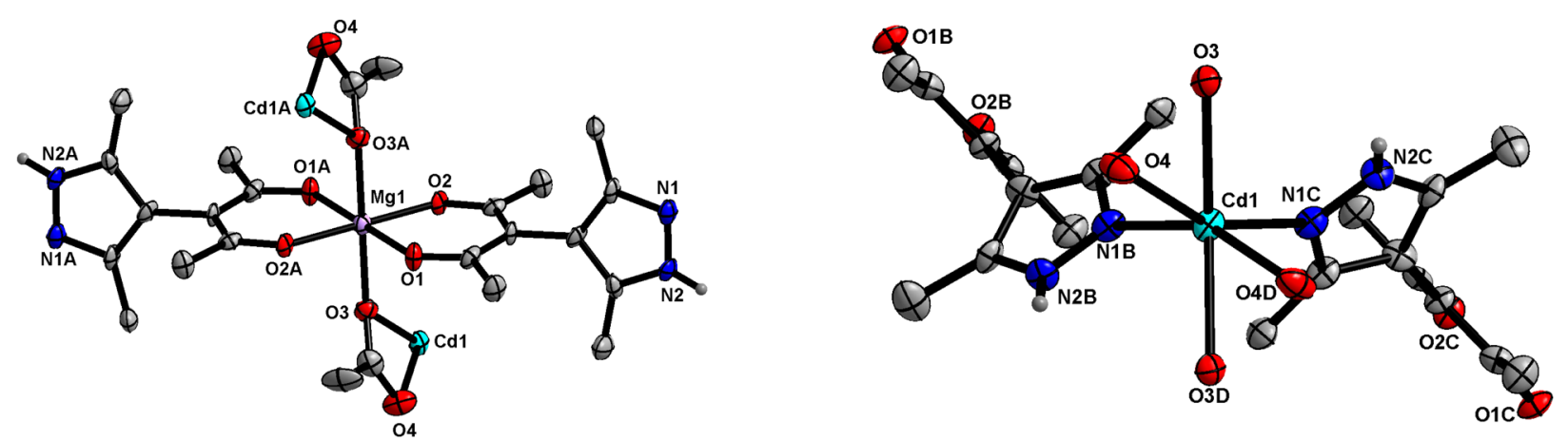

Figure 5. Coordination of a $\mathrm{Mg}(\mathrm{II})$ cation (left) and $\mathrm{Cd}(\mathrm{II})$ (right) in the crystal structure of $\mathbf{5}$. Ellipsoids are drawn at $50 \%$ probability level. Symmetry operations: $\mathrm{A}=0.5-x, 1.5-y, 1-z ; \mathrm{B}=0.5+x, 0.5+y, z ; \mathrm{C}=0.5-x, 0.5+y, 1.5-z ; \mathrm{D}=1-x, y, 1.5-z$. 

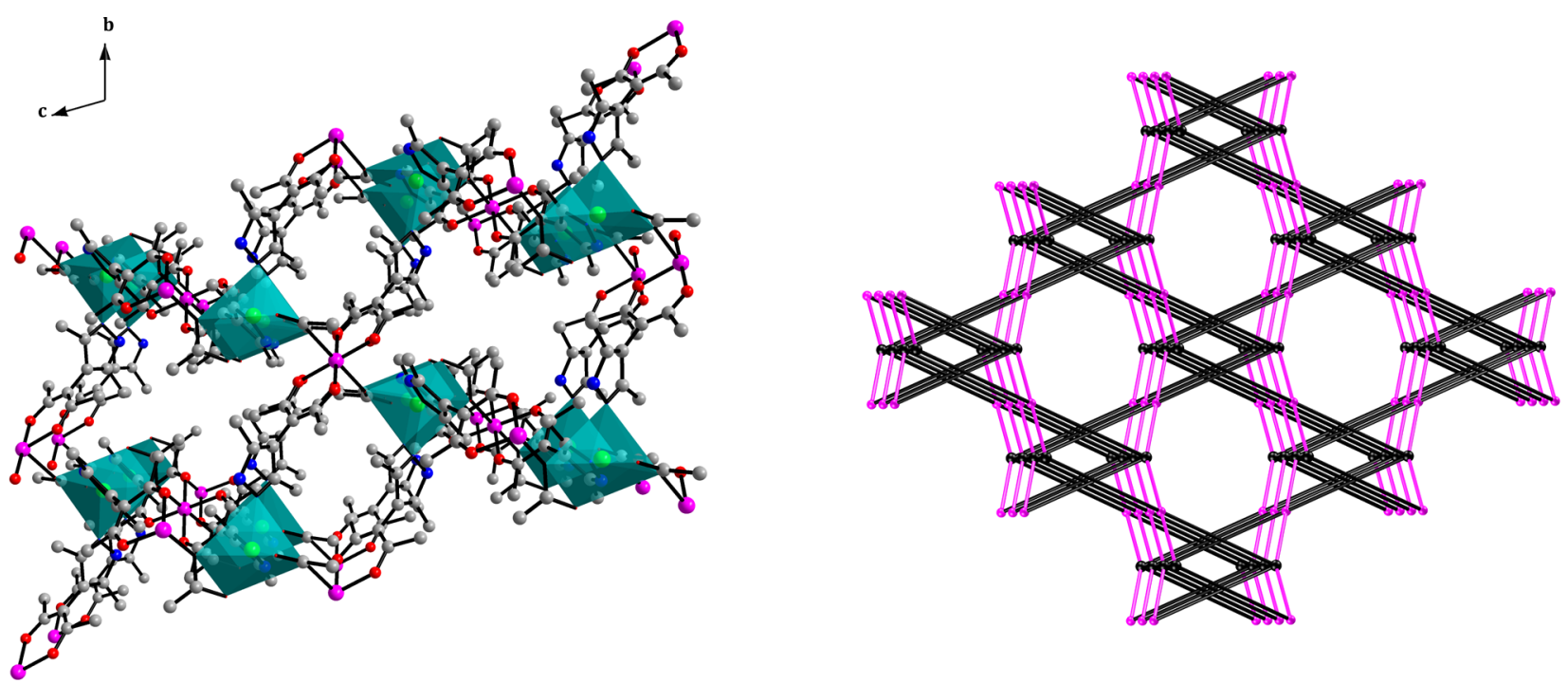

Figure 6. Perspective view of the 3D network of the bimetallic coordination polymer 5. Six-coordinated Cd is drawn in polyhedron mode (left); schematic illustrating the 3D topology in 5. Color code: pink node, $\mathrm{Mg}$ (II) center; black node, $\mathrm{Cd}(\mathrm{II})$ center; pink stick, acetate linker; black stick, $\mathrm{HacacPz} z^{-}$linker (right).

with $\mathrm{Be}-\mathrm{O}$ distances of $1.60 \AA$, whereas the $\mathrm{Mg}-\mathrm{O}$ distances in 4 range between 2.0 and $2.1 \AA$ and the bite angle of the $\mathrm{HacacPz}$ ligand amounts to $86^{\circ}$.

With respect to crystal engineering, the $N$ coordinated complexes 1-3 and the $O$ coordinated compound 4 show distinctly different behavior: our attempts to cross-link the dangling acetylacetone moieties in the former did not yet lead to isolated crystalline reaction products, whereas further $N$ coordination of 4 was successful. In the following section, we will discuss the resulting mixed-metal coordination compound 5.

The $\mathrm{Mg}-\mathrm{O}$ bonds to the coordinated $\mathrm{MeOH}$ molecules represent the predetermined breaking points in 4: equimolar reaction with cadmium acetate gives additional coordination of a Cd-coordinated acetate oxygen to the alkaline earth cation. In parallel, the pyrazolic $\mathrm{N}$ donor completes the octahedral coordination about a symmetry-equivalent $\mathrm{Cd}(\mathrm{II})$. The reaction stoichiometry and a first interpretation of the single crystal diffraction experiment on solid 5 suggest the overall composition $\mathrm{Mg}(\mathrm{HacacPz})_{2} \mathrm{Cd}\left(\mathrm{OOCCH}_{3}\right)_{2}$. In line with this hypothesis, a coordination sphere with $\overline{1}$ site symmetry made up entirely of oxygen atoms is observed for $\mathrm{Mg}$ (Figure 5, left), whereas the softer $\mathrm{Cd}$ cation is situated on a 2 -fold axis in a mixed nitrogen-oxygen $\mathrm{N}_{2} \mathrm{O}_{4}$ environment (Figure 5, right). In the Introduction, we suggested an approximate cation... cation distance subtended by the HacacPz ligand of ca. $9 \AA$, and we can now confirm this estimate: the ditopic ligand in $\mathbf{5}$ bridges a $\mathrm{Mg} \cdots \mathrm{Cd}$ of $9.1 \AA$.

Closer inspection of the diffraction results, however, indicated a slightly more complicated situation: refinement of the well-ordered structure model as described above converged with an unrealistically small displacement parameter for the $\mathrm{Mg}$ cation. This exclusively $O$ coordinated site is not completely occupied by the alkaline earth cation but also to a minor extent by $\mathrm{Cd}(\mathrm{II})$. Figure S2 in the Supporting Information compiles displacement parameter plots for tentative variations in the occupancy factors: visual inspection confirms a low Cd(II) content. Our final structure model is based on site occupancy refinement in which the sum of the occupancies was constrained to unity; it converged for $93.5(3) \%$ of $\mathrm{Mg}$ and
$6.5(3) \%$ of $\mathrm{Cd}$. We recall that the solid thus characterized, 5a, was obtained from a reaction with $4: \mathrm{Cd}\left(\mathrm{OOCCH}_{3}\right)_{2}=1: 1$ stoichiometry. Our interpretation of the disordered cation site is corroborated by the existence of an isomorphous solid: $\mathbf{5 b}$ crystallizes in the presence of an excess of cadmium actetate and shows a $\mathrm{Mg}: \mathrm{Cd}=86.3(4): 13.7(4)$ ratio for the occupancy of the oxygen-coordinated cation. The information about partial occupancy of the $\mathrm{O}$ six-coordinated cation site by $\mathrm{Cd}$ stems mostly from the very pronounced difference in electron density between $\mathrm{Mg}$ and $\mathrm{Cd}$; we also note, however, that cation-oxygen distances in $\mathbf{5 b}$ are slightly longer than those in 5a, in agreement with the more pronounced site occupancy by the larger $\mathrm{Cd}(\mathrm{II})$ cation. $\mathbf{5} \mathbf{a}$ and $\mathbf{5 b}$ represent two individual compositions of a solid solution 5 in which the $\mathrm{Mg}$ (II) cation may be partially replaced by $\mathrm{Cd}(\mathrm{II})$. How surprising is this type of substitutional disorder? The elements $\mathrm{Mg}$ and $\mathrm{Cd}$ both adopt hexagonal close packing but clearly differ in their intermetal distances. As for their divalent cations, $\mathrm{Cd}$ (II) (1.09 $\AA)$ is significantly larger than $\mathrm{Mg}$ (II) $(0.86 \AA)^{38}$ and much softer with respect to Pearson hardness. ${ }^{39}$ Toward oxygen, both cations prefer coordination number 6; a compilation of CSDbased $^{32}$ frequencies for different coordination numbers is provided in the Supporting Information (Figure S20). We are aware of only one crystal structure for which substitutional disorder between $\mathrm{Mg}(\mathrm{II})$ and $\mathrm{Cd}(\mathrm{II})$ has been reported: Yao and co-workers ${ }^{40}$ have encountered a related case of a sixcoordinated cation site preferentially occupied by $\mathrm{Mg}(\mathrm{II})$, together with a small (7\%) Cd(II) content.

5 forms a three-dimensional coordination network (Figure 6, left). With respect to topology, each $\mathrm{Mg}$ and $\mathrm{Cd}$ dication may be perceived as a 4-connected node. The resulting binodal $(4,4)$ net can be assigned the vertex symbol $\left(4.4 .8_{2} \cdot 8_{2} \cdot 8_{8} .8_{8}\right)\left(4.4 .8_{7}\right.$. $\left.87.8_{7} .8_{7}\right),{ }^{41}$ which corresponds to a pts net. ${ }^{42} \mathrm{~A}$ simplified view of the topology is shown in Figure 6, right. ${ }^{43}$

The Raman spectra for solids 4 and 5 show a band at ca. 400 $\mathrm{cm}^{-1}$ which is absent in those of $\mathbf{1 - 3}$. We tentatively assign this resonance to $\mathrm{Mg}-\mathrm{O}$ stretching. 


\section{CONCLUSION}

Employing cations of different Pearson hardness, we have been able to selectively deprotonate the soft $\mathrm{N}$ and the hard $\mathrm{O}$ donor site of the pyrazolyl-substituted acetylacetone $\mathrm{H}_{2}$ acacPz. Future work will be dedicated to the fluorescence properties of the discrete molecular species 3 . We will also attempt to synthesize mixed-metal coordination polymers involving $\mathrm{Ag}$ and $\mathrm{Yb}$ cations: decomposition of such compounds has led to catalytically active agglomerates of silver nanoparticles and rare-earth oxide. ${ }^{44}$

\section{EXPERIMENTAL SECTION}

Materials and Methods. All chemicals were used without further purification: $\mathrm{ZnCl}_{2}$ (99\%, Grüssing), $\mathrm{AgNO}_{3}$ (KMF), silver benzoate (99\%, Acros), $\mathrm{Mg}$ (99.8\%, Fluka), cadmium acetate (97\%, Kraft Bernd), and dimethyl sulfoxide- $d_{6}$ (99.9 atom \%D, Aldrich).

IR spectra were recorded on a Nicolet Avatar 360 E.S.P. spectrometer in $\mathrm{KBr}$ windows. Raman spectra were obtained with a Horiba LABRAM HR instrument equipped with a $633 \mathrm{~nm} \mathrm{HeNe}$ excitation laser. The electron-impact mass spectrum of $\mathrm{H}_{2} \mathrm{acacPz}$ was recorded on a Finnigan MAT-95 at a nominal electron energy of 70 $\mathrm{eV}$. CHN microanalyses were carried out at the Institute of Organic Chemistry, RWTH Aachen University, using a HERAEUS CHNORapid. Powder diffraction experiments were performed at room temperature on flat samples with a Stoe \& Cie STADI P diffractometer equipped with an image plate detector with a constant $\omega$ angle of $55^{\circ}$ using germanium-monochromated $\mathrm{Cu}-\mathrm{K} \alpha_{1}$ radiation $(\lambda=1.54051$ $\AA) .{ }^{1} \mathrm{H}$ NMR spectra were measured with a Bruker Avance II UltrashieldTM plus 400 instrument (400 MHz, referenced to TMS).

Syntheses. Synthesis of $\mathrm{H}_{2} a c a c P z$. The $\mathrm{H}_{2} \mathrm{acacPz}$ ligand was prepared according to the literature method by Mosby. ${ }^{45-47}$ Spectroscopic data: ${ }^{1} \mathrm{H}$ NMR $\left(d_{6}\right.$-DMSO): $\delta=16.98(\mathrm{~s}, 1 \mathrm{H}$, $-\mathrm{OH}), 12.33(\mathrm{~s}, 1 \mathrm{H},-\mathrm{NH}), 2.06\left(\mathrm{~s}, 6 \mathrm{H},-\mathrm{CH}_{3}\right), 1.87(\mathrm{~s}, 6 \mathrm{H}$, $\left.-\mathrm{CH}_{3}\right)$. Broadening of the signal at $2.06 \mathrm{ppm}$ associated with the methyl groups in the acetylacetone part of the ligand (Figure S21) is due to keto-enol tautomerism. Deprotonation of this part of the ligand as in 4 results in a narrow line. ${ }^{48-51}$ MS-EI: $\mathrm{m} / z$ calcd for $\left[\mathrm{C}_{10} \mathrm{H}_{14} \mathrm{~N}_{2} \mathrm{O}_{2}\right]^{+}$: 194.1055; found: 194.1 .

Synthesis of $\mathrm{Zn}\left(\mathrm{H}_{2} \mathrm{acacPz}\right)_{2} \mathrm{Cl}_{2}, 1 . \mathrm{H}_{2} \mathrm{acacPz}(9.7 \mathrm{mg}, 0.05 \mathrm{mmol})$ and $\mathrm{ZnCl}_{2}$ (3.4 mg, $\left.0.025 \mathrm{mmol}\right)$ were dissolved in methanol $(2 \mathrm{~mL})$ and stirred for $10 \mathrm{~min}$ at ambient temperature. The clear solution was left unperturbed for slow evaporation. Colorless crystals grew over a period of 1 week. Yield: $10.2 \mathrm{mg}(0.019 \mathrm{mmol}, 76 \%)$. Phase purity of the product was confirmed by powder diffraction of the bulk material (see Figure S15, Supporting Information).

Anal. Calcd for $\mathrm{C}_{20} \mathrm{H}_{28} \mathrm{Cl}_{2} \mathrm{~N}_{4} \mathrm{O}_{4} \mathrm{Zn}$ : C: $45.78, \mathrm{H}: 5.38, \mathrm{~N}: 10.68$.

Found: C: 45.04, H: 5.95, N: 10.20 .

Synthesis of $\left[\mathrm{Ag}\left(\mathrm{H}_{2} \mathrm{acacPz}\right)_{2}\right] \mathrm{NO}_{3} \cdot \mathrm{H}_{2} \mathrm{O}, 2 . \mathrm{AgNO}_{3}(4.2 \mathrm{mg}, 0.025$ $\mathrm{mmol}$ ) was dissolved in one drop of water, and $1 \mathrm{~mL}$ of methanol was added. $\mathrm{H}_{2} \mathrm{acacPz}(9.7 \mathrm{mg}, 0.05 \mathrm{mmol})$ was dissolved in $\mathrm{MeOH}$ (1 $\mathrm{mL}$ ). These two solutions were combined and stirred for $10 \mathrm{~min}$ at ambient temperature. The clear reaction mixture was left unperturbed for slow evaporation. Colorless crystals grew over a period of 1 week. Yield: $7.2 \mathrm{mg}(0.012 \mathrm{mmol}, 48 \%)$. Phase purity of the product was confirmed by powder diffraction of the bulk material (see Figure S16, Supporting Information).

Anal. Calcd for $\mathrm{C}_{20} \mathrm{H}_{30} \mathrm{AgN}_{5} \mathrm{O}_{8}$ : C: 41.68, H: 5.25, N: 12.15 .

Found: C: 42.01, H: 5.67, N: 11.61.

Synthesis of $\left[\mathrm{Ag}_{6}(\mathrm{HacacPz})_{6}\right] \cdot 2 \mathrm{EtOH}, 3 a_{;}\left[\mathrm{Ag}_{6}\left(\mathrm{HacacPz}_{6}\right] \cdot 4 \mathrm{EtOH}\right.$, $3 b$; and $\left[\mathrm{Ag}_{6}(\mathrm{HacacPz})_{6}\right] \cdot 0.5 \mathrm{CH}_{2} \mathrm{Cl}_{2} \cdot 1.5 \mathrm{C}_{4} \mathrm{H}_{10} \mathrm{O}, 3 \mathrm{c}$. Solutions of $\mathrm{Ag}(\mathrm{PhCOO})(11.5 \mathrm{mg}, 0.05 \mathrm{mmol})$ in THF $(2 \mathrm{~mL})$ and $\mathrm{H}_{2} \mathrm{acacPz}$ $(9.7 \mathrm{mg}, 0.05 \mathrm{mmol})$ in $\mathrm{MeOH}(2 \mathrm{~mL})$ were combined. The mixture was stirred for $12 \mathrm{~h}$ at ambient temperature, and the phases were separated by centrifugation. The supernatant liquid was discarded, and the solid residue was washed twice with $\mathrm{MeOH}(2 \mathrm{~mL})$. Yield: $9.6 \mathrm{mg}$ of $\mathrm{Ag}_{6}(\mathrm{HacacPz})_{6}(0.0053 \mathrm{mmol}, 64 \%)$. Colorless block-shaped crystals of $\mathbf{3 a}$ and $\mathbf{3 b}$ were obtained by slow diffusion of EtOH into a $\mathrm{CH}_{2} \mathrm{Cl}_{2}$ solution of $\mathrm{Ag}_{6}(\mathrm{HacacPz})_{6}$ within 2 days. Crystals of $3 \mathrm{c}$ were prepared in an analogous way using 2-butanol instead of EtOH as antisolvent in diffusion. All solvates of $\mathbf{3}$ lose solvent very fast, as evidenced by powder diffraction. When solid $3 \mathbf{a}$ is freshly isolated, hardly ground, and subjected to powder diffraction with the protection of perfluoropolyallylether, the powder pattern of the bulk is in agreement with the expectation from the single crystal structure (see the Supporting Information, Figure S17). No fully satisfactory elemental analysis has been obtained for 3 .

Anal. Calcd for $\mathrm{C}_{60} \mathrm{H}_{78} \mathrm{Ag}_{6} \mathrm{~N}_{12} \mathrm{O}_{12}$ : C: $39.89, \mathrm{H}: 4.35, \mathrm{~N}: 9.30$.

Found: C: $37.43, \mathrm{H}: 4.37, \mathrm{~N}: 9.34$.

Synthesis of $\left[\mathrm{Mg}(\mathrm{HacacPz})_{2}(\mathrm{MeOH})_{2}\right] \cdot 2 \mathrm{MeOH}$, 4. Magnesium methoxide was prepared by reaction of $\mathrm{Mg}(23.9 \mathrm{mg}, 1 \mathrm{mmol})$ with dry $\mathrm{MeOH}(10 \mathrm{~mL})$ at room temperature; a standard Schlenk technique was used to exclude moisture and oxygen. This magnesium methoxide solution was combined with a solution of $\mathrm{H}_{2} \mathrm{acacPz}$ (388.5 $\mathrm{mg}, 2 \mathrm{mmol}$ ) in dry $\mathrm{MeOH}$ and stirred for $3 \mathrm{~h}$. The colorless precipitate consisted of larger crystals. It was recovered by filtration and washed with ca. $0.5 \mathrm{~mL}$ of cold $\mathrm{MeOH}$ and dried in a desiccator. Yield: $299.3 \mathrm{mg}(0.63 \mathrm{mmol}, 63 \%)$. The methanol solvate 4 undergoes fast desolvation, as evidenced by powder diffraction. When solid $\mathbf{4}$ is freshly isolated, hardly ground, and subjected to powder diffraction with the protection of perfluoropolyallylether, the powder pattern indicates concomitant presence of solvated and desolvated material (see the Supporting Information, Figure S18).

Anal. Calcd for $\mathrm{C}_{22} \mathrm{H}_{34} \mathrm{MgN}_{4} \mathrm{O}_{6}$ (desolvation of uncoordinated $\mathrm{MeOH}): \mathrm{C}: 55.65, \mathrm{H}: 7.22, \mathrm{~N}: 11.80$.

Found: C: 54.60, H: 6.62, N: 12.70

Synthesis of $\mathrm{Mg}_{1-x} \mathrm{Cd}_{x}(\mathrm{HacacPz})_{2} \mathrm{Cd}\left(\mathrm{OOCCH}_{3}\right)_{2}, 5$. In a test tube, 4 $(9.5 \mathrm{mg}, 0.02 \mathrm{mmol})$ was dissolved in a mixture of $\mathrm{MeOH} / \mathrm{CH}_{2} \mathrm{Cl}_{2}(1$ $\mathrm{mL} / 1 \mathrm{~mL})$. The solution was layered by a mixture of $0.5 \mathrm{~mL}$ of $\mathrm{CH}_{2} \mathrm{Cl}_{2}$ and $0.5 \mathrm{~mL}$ of $\mathrm{MeOH}$. A top layer of $\mathrm{Cd}\left(\mathrm{OOCCH}_{3}\right)_{2} \cdot \mathrm{H}_{2} \mathrm{O}$ $(5.3 \mathrm{mg}, 0.02 \mathrm{mmol})$ in $1 \mathrm{~mL}$ of $\mathrm{MeOH}$ was added, and the test tube was left unperturbed at room temperature for crystallization by diffusion. Colorless crystals of $\mathbf{5 a}$ formed within 2 days. The composition $\mathrm{Mg}_{1-x} \mathrm{Cd}_{x}(\mathrm{HacacPz})_{2} \mathrm{Cd}\left(\mathrm{OOCCH}_{3}\right)_{2}, x=0.065(3)$, was determined by single crystal X-ray diffraction. Yield: $8.2 \mathrm{mg}$ $(0.013 \mathrm{mmol}, 65 \%)$. Phase purity of the product was confirmed by powder diffraction of the bulk material (see Figure S19, Supporting Information).

When an excess of cadmium acetate was used by changing the reaction stoichiometry $\mathbf{4}: \mathrm{Cd}\left(\mathrm{OOCCH}_{3}\right)_{2} \cdot \mathrm{H}_{2} \mathrm{O}$ to $1: 2$, the solid $\mathbf{5} \mathbf{b}$ was obtained. It is isomorphous to 5a, with $x=0.137(4)$. Yield: $9.7 \mathrm{mg}$ $(0.015 \mathrm{mmol}, 75 \%)$. No fully satisfactory elemental analysis was obtained for 5 .

Crystallographic Studies. Crystal data, data collection parameters and convergence results have been compiled in Tables $2(\mathbf{1}, \mathbf{2}, \mathbf{3} \mathbf{a}, \mathbf{3 b})$ and $3(\mathbf{3 c}, \mathbf{4}, \mathbf{5 a}, \mathbf{5 b})$. The diffraction experiments were performed with a Bruker D8 goniometer equipped with an Incoatec microsource (Mo-K $\alpha, \lambda=0.71073 \AA$, multilayer optics) and an APEX CCD detector; a sample temperature of $100(2) \mathrm{K}$ was maintained with an Oxford Cryostream 700 instrument. Intensity data were integrated with SAINT $+{ }^{52}$ and corrected for absorption by multiscan methods using the program SADABS. ${ }^{53}$

The crystal structures were solved with Patterson or Direct methods, and refinements were accomplished with full-matrix leastsquares procedures as implemented in SHELXL-13. ${ }^{54}$ All nonhydrogen atoms were assigned anisotropic displacement parameters; hydrogen atoms were placed in idealized positions and included as riding with constrained isotropic displacement parameters. In $\mathbf{1 - 5}$, the hydrogen atoms of the hydroxyl group and secondary amine were located according to the following strategy: (1) tentative assignment of local electron density maxima from Fourier difference maps, followed by refinement with distance restraints; (2) in the absence of geometrically acceptable electron density maxima, positions in the direction of a suitable hydrogen bond acceptor were calculated and also subjected to distance restraints; (3) if neither matching electron density maxima nor suitable hydrogen bond acceptors were available, $\mathrm{H}$ atoms were calculated in standard distance in arbitrary orientation.

In 2, the nitrate anion and the water molecule are disordered about a crystallographic center of inversion; the situation is depicted in 
Figure S1. For reasons of symmetry and charge balance, the mutually exclusive components were assigned half occupancy and a common isotropic displacement parameter in the least-squares refinement. In 3a, the solvent molecule was refined as ethanol with similarity restraints for its displacement parameters. The assignment of EtOH to the electron density in the solvent-containing void was in agreement with a tentative SQUEEZE ${ }^{55}$ calculation. Electron density in the solvent-accessible voids of $\mathbf{3 b}$ was handled with the SQUEEZE ${ }^{55}$ algorithm. The ${ }^{1} \mathrm{H}$ NMR spectra for $3 \mathrm{c}$ confirmed the identity of the chlathrated solvents $\mathrm{CH}_{2} \mathrm{Cl}_{2}$ and 2-butanol. Distance and displacement similarity restraints were used for the refinement of the $\mathrm{CH}_{2} \mathrm{Cl}_{2}$ molecule; its occupancy converged to ca. 0.5. No structure model could be obtained for 2-butanol because of severe disorder. Therefore, in the final structure model for $3 \mathrm{c}$, atoms in the $\mathrm{CH}_{2} \mathrm{Cl}_{2}$ molecule were assigned half occupancy and the electron density in the remaining solvent-accessible voids was handled with the SQUEEZE ${ }^{55}$ algorithm. In $\mathbf{5 a}$, the exclusively $O$ coordinated cation showed substitutional disorder: in addition to its major occupancy by $\mathrm{Mg}$, a minor site occupancy of $\mathrm{Cd}$ was detected. Coordinates and displacement parameters for the alternative cations were constrained to be equal, and the sum of their site occupancies was constrained to unity. The relative site occupancy converged to a $\mathrm{Mg}$ : $\mathrm{Cd}$ ratio of 93.5(3):6.5(3). The same type of substitutional disorder was detected in $\mathbf{5 b} \mathbf{b}$, albeit with a higher Cd content of 13.7(4)\%. After refinement of the disorder model for $\mathbf{5} \mathbf{b}$, a list of disagreeable reflections showed a clear tendency for $F^{2}$ (obs.) $\gg F^{2}$ (calc.). A test with the TwinRotMat option in PLATON $^{56}$ confirmed nonmerohedral twinning for this sample, with 375 out of 3066 reflections overlapping. An appropriately modified set of intensity data taking the partially overlapped diffraction of both domains into account (HKLF5 format in SHELXL97 ${ }^{57}$ ) gave significantly improved convergence results and relative domain fractions of 0.82 and 0.18 .

\section{ASSOCIATED CONTENT}

\section{S Supporting Information}

The Supporting Information is available free of charge on the ACS Publications website at DOI: 10.1021/acs.cgd.6b00710.

Illustration of the disordered nitrate anion and water molecule in 2; illustration of the refinement results with variable minor site occupancy by $\mathrm{Cd}$ (II) in 5a; infrared spectra for $\mathrm{H}_{2} \mathrm{acacPz}, 1,2,3,4$ and 5; Raman spectra for 1-5; powder patterns for 1-5; histogram showing coordination numbers for $\mathrm{Mg}(\mathrm{II})$ and $\mathrm{Cd}(\mathrm{II})$ in exclusively $O$ coordinated environments; ${ }^{1} \mathrm{H}$ NMR spectrum of $\mathrm{H}_{2}$ acacPz in $d_{6}$-DMSO; ${ }^{1} \mathrm{H}$ NMR spectrum of 4 in $d_{6}$-DMSO; $\mathrm{Ag} \cdots \mathrm{Ag}$ distances of $\mathrm{Ag}_{6}(\mathrm{HacacPz})_{6}$ aggregates in compounds $\mathbf{3 a}, \mathbf{3 b}$, and $\mathbf{3 c}$; and hydrogen bond information on 4 . (PDF)

\section{Accession Codes}

CCDC 1478683-1478690 contains the supplementary crystallographic data for this paper. These data can be obtained free of charge via www.ccdc.cam.ac.uk/data_request/cif, or by emailingdata_request@ccdc.cam.ac.uk, or by contacting The Cambridge Crystallographic Data Centre, 12, Union Road, Cambridge CB2 1EZ, UK; fax: +44 1223336033.

\section{AUTHOR INFORMATION}

\section{Corresponding Author}

*E-mail: ullrich.englert@ac.rwth-aachen.de. Phone: +49-2418094666. Fax: +49-241-8092288.

\section{Notes}

The authors declare no competing financial interest.

\section{ACKNOWLEDGMENTS}

Financial support by the China Scholarship Council (Q.G.) is gratefully acknowledged. We thank Irmgard Kalf for help with the Raman spectra.

\section{REFERENCES}

(1) Silvernail, C. M.; Yap, G.; Sommer, R. D.; Rheingold, A. L.; Day, V. W.; Belot, J. A. Polyhedron 2001, 20, 3113-3117.

(2) Burrows, A. D. CrystEngComm 2011, 13, 3623-3642.

(3) Kondracka, M.; Englert, U. Inorg. Chem. 2008, 47, 10246-10257.

(4) Merkens, C.; Englert, U. Dalton Trans. 2012, 41, 4664-4673.

(5) Merkens, C.; Becker, N.; Lamberts, K.; Englert, U. Dalton Trans. 2012, 41, 8594-8599.

(6) Burrows, A. D.; Cassar, K.; Mahon, M. F.; Warren, J. E. Dalton Trans. 2007, 2499-2509.

(7) Merkens, C.; Pecher, O.; Steuber, F.; Eisenhut, S.; Görne, A.; Haarmann, F.; Englert, U. Z. Anorg. Allg. Chem. 2013, 639, 340-346.

(8) Guo, Q.; Merkens, C.; Si, R.; Englert, U. CrystEngComm 2015, $17,4383-4393$.

(9) Mackay, L. G.; Anderson, H. L.; Sanders, J. K. M. J. Chem. Soc., Chem. Commun. 1992, 43-44.

(10) Vreshch, V. D.; Chernega, A. N.; Howard, J. A. K.; Sieler, J.; Domasevitch, K. V. Dalton Trans. 2003, 1707-1711.

(11) Merkens, C.; Truong, K.-N.; Englert, U. Acta Crystallogr., Sect. B: Struct. Sci., Cryst. Eng. Mater. 2014, B70, 705-713.

(12) Chen, B.; Fronczek, F. R.; Maverick, A. W. Inorg. Chem. 2004, 43, 8209-8211.

(13) Vreshch, V. D.; Lysenko, A. B.; Chernega, A. N.; Howard, J. A. K.; Krautscheid, H.; Sieler, J.; Domasevitch, K. V. Dalton Trans. 2004, 2899-2903.

(14) Vreshch, V. D.; Lysenko, A. B.; Chernega, A. N.; Sieler, J.; Domasevitch, K. V. Polyhedron 2005, 24, 917-926.

(15) Zhang, Y.; Chen, B.; Fronczek, F. R.; Maverick, A. W. Inorg. Chem. 2008, 47, 4433-4435.

(16) Merkens, C.; Pan, F.; Englert, U. CrystEngComm 2013, 15, $8153-8158$

(17) Boldog, I.; Rusanov, E. B.; Chernega, A. N.; Sieler, J.; Domasevitch, K. V. Angew. Chem., Int. Ed. 2001, 40, 3435-3438.

(18) Pearson, R. G. Chemical Hardness: Applications from Molecules to Solids; Wiley-VCH: Weinheim, 1997.

(19) Nakamoto, K. Infrared and Raman Spectra of Inorganic and Coordination Compounds. Part B: Applications in Coordination, Organometallic and Bioinorganic Chemistry, 6th ed.; Wiley-VCH: Weinheim, 2009.

(20) Creighton, J.; Albrecht, M.; Hester, R.; Matthew, J. Chem. Phys. Lett. 1978, 55, 55-58.

(21) Omary, M. A.; Webb, T. R.; Assefa, Z.; Shankle, G. E.; Patterson, H. H. Inorg. Chem. 1998, 37, 1380-1386.

(22) Chu, Q.; Swenson, D. C.; MacGillivray, L. R. Angew. Chem., Int. Ed. 2005, 44, 3569-3572.

(23) Dobrzaǹska, L.; Raubenheimer, H. G.; Barbour, L. J. Chem. Commun. 2005, 5050-5052.

(24) Park, B. I.; Lee, J. W.; Lee, Y.-A.; Hong, J.; Jung, O.-S. Bull. Chem. Soc. Jpn. 2005, 78, 1624-1628.

(25) Kalf, I.; Braun, M.; Wang, Y.; Englert, U. CrystEngComm 2006, $8,916-922$.

(26) Liu, X.; Guo, G.-C.; Fu, M.-L.; Liu, X.-H.; Wang, M.-S.; Huang, J.-S. Inorg. Chem. 2006, 45, 3679-3685.

(27) Wang, Y.; Şerb, M.; Englert, U. Struct. Chem. 2010, 21, 203211.

(28) Wang, Y.; Englert, U. Inorg. Chim. Acta 2010, 363, 2539-2545. (29) Kalf, I.; Mathieu, P.; Englert, U. New J. Chem. 2010, 34, 24912495.

(30) Schmidbaur, H.; Schier, A. Angew. Chem., Int. Ed. 2015, 54, 746-784.

(31) Groom, C. R.; Allen, F. H. Angew. Chem., Int. Ed. 2014, 53, $662-671$ 
(32) CSD Version 5.36; CCDC: Cambridge, U.K., including updates until Feb. 2016.

(33) Morishima, Y.; Young, D. J.; Fujisawa, K. Dalton Trans. 2014, 43, 15915-15928.

(34) Dias, H. R.; Diyabalanage, H. V. Polyhedron 2006, 25, 16551661.

(35) Mohamed, A. A.; Pérez, L. M.; Fackler, J. P., Jr Inorg. Chim. Acta 2005, 358, 1657-1662.

(36) Veronelli, M.; Kindermann, N.; Dechert, S.; Meyer, S.; Meyer, F. Inorg. Chem. 2014, 53, 2333-2341.

(37) Puszynska-Tuszkanow, M.; Staszak, Z.; Misiaszek, T.; Klepka, M. T.; Wolska, A.; Drzewiecka-Antonik, A.; Faltynowicz, H.; CieslakGolonka, M. Chem. Phys. Lett. 2014, 597, 94-98.

(38) Shannon, R. D. Acta Crystallogr., Sect. A: Cryst. Phys., Diffr., Theor. Gen. Crystallogr. 1976, A32, 751-767.

(39) Pearson, R. G. J. Am. Chem. Soc. 1963, 85, 3533-3539.

(40) Zhang, X.; Huang, Y.-Y.; Lin, Q.-P.; Zhang, J.; Yao, Y.-G. Dalton Trans. 2013, 42, 2294-2301.

(41) Lamberts, K.; Merkens, C.; Wang, R.; Englert, U.; Hons, D.; Grüter, S.; Guo, Y.; Porsche, S.; Hamacher, A.; Bündgens, D.; Kuhlen, T. Z. Kristallogr. Suppl. 2012, 32, 117.

(42) O’Keeffe, M.; Peskov, M. A.; Ramsden, S. J.; Yaghi, O. M. Acc. Chem. Res. 2008, 41, 1782-1789.

(43) Dolomanov, O. V.; Blake, A. J.; Champness, N. R.; Schröder, M. J. Appl. Crystallogr. 2003, 36, 1283-1284.

(44) Konkol, M.; Kondracka, M.; Kowalik, P.; Próchniak, W.; Michalska, K.; Schwedt, A.; Merkens, C.; Englert, U. Appl. Catal., B 2016, 190, 85-92.

(45) Charles, R. G. Org. Synth. 1959, 39, 61-63.

(46) Ponomarova, V. V.; Komarchuk, V. V.; Boldog, I.; Krautscheid, H.; Domasevitch, K. V. CrystEngComm 2013, 15, 8280.

(47) Mosby, W. L. J. Chem. Soc. 1957, 3997-4003.

(48) Drexler, E. J.; Field, K. W. J. Chem. Educ. 1976, 53, 392-393.

(49) Folkendt, M. M.; Weiss-Lopez, B. E.; Chauvel, P. J., Jr.; True, N. S. J. Phys. Chem. 1985, 89, 3347-3352.

(50) Martínez-Richa, A.; Mendoza-Díaz, G.; Joseph-Nathan, P. Appl. Spectrosc. 1996, 50, 1408-1412.

(51) Abood, N. A.; Ajam, A. F. J. Chem. Soc. Pak. 1985, 7, 1-6.

(52) SAINT+ (version 7.68): Program for Reduction of Data Collected on Bruker CCD Area Detector Diffractometer; Bruker AXS, Inc.: Fitchburg, WI, 2009.

(53) Sheldrick, G. M. SADABS (version 2.03): Program for Empirical Absorption Correction of Area Detector Data; University of Göttingen: Göttingen, Germany, 2004.

(54) Sheldrick, G. M. Acta Crystallogr. 2015, C71, 3-8.

(55) van der Sluis, P.; Spek, A. L. Acta Crystallogr., Sect. A: Found. Crystallogr. 1990, A46, 194-201.

(56) Spek, A. L. Acta Crystallogr., Sect. D: Biol. Crystallogr. 2009, D65, $148-155$.

(57) Sheldrick, G. M. Acta Crystallogr., Sect. A: Found. Crystallogr. 2008, A64, 112-122. 